\title{
First optical education center in Japan established by cooperation between academia and industry
}

\section{Toyohiko Yatagai}

Toyohiko Yatagai, "First optical education center in Japan established by cooperation between academia and industry," Proc. SPIE 9289, 12th Education and Training in Optics and Photonics Conference, 928928 (17 July 2014); doi: 10.1117/12.2070725

Event: 12th Education and Training in Optics and Photonics Conference, 2013, Porto, Portugal 


\title{
First Optical Education Center in Japan, Established by Cooperation between Academia and Industry
}

\author{
Toyohiko Yatagai \\ Center for Optical Research and Education, Utsunomiya University
}

At the present of the 21 st century, optical technology became what must be in our life. If there is no optical technology, we cannot use optical equipments such as the camera, microscopes, DVD, LEDs and laser diodes (LDs). Optics is also the leading part in the most advanced scientific field. It is clear that the organization which does education and research is required in such a very important area. Unfortunately, there was no such organization in Japan. The education and research of light have been individually done in various faculties of universities, various research institutes, and many companies.

However, our country is now placed in severer surroundings, such as the globalization of our living, the accelerated competition in research and development. This is one of the reasons why Utsunomiya University has established Center for Optical Research and Education (CORE) in 2007. To contribute to optical technology and further development of optical industry, "Center for Optical Research and Education (CORE), Utsunomiya University" promotes education and research in the field of the optical science and technology cooperatively with industry, academia and the government.

Currently, 6 full professors, 21 cooperative professors, 2 visiting professors and 7 post-doctoral researchers and about 40 students are joined with CORE. Many research projects with industries, the local government of Tochigi as well as Japanese government. Optical Innovation Center has established in CORE by supporting of Japan Science and Technology Agency in 2011 to develop advanced optical technologies for local companies.

\footnotetext{
12th Education and Training in Optics and Photonics Conference, edited by

Manuel F. P. C. Martins Costa, Mourad Zghal, Proc. of SPIE Vol. 9289, 928928

(C) 2014 SPIE, OSA, IEEE, ICO · doi: 10.1117/12.2070725
} 